\title{
The Gender Gap in Agricultural Productivity in Kyrgyzstan
}

\author{
Asst. Prof. Dr. Burulcha Sulaimanova (Kyrgyz-Turkish Manas University, Kyrgyzstan) \\ Daniyar Jasoolov (Public Fund AVEP, Kyrgyzstan)
}

\begin{abstract}
More than two third of total population of Kyrgyzstan are living in rural areas, and the agricultural sector of Kyrgyzstan employs nearly the half of labor force and have export oriented output production with over than 384 thousand peasant farms. The share of employed women in agriculture compromised the $44 \%$ of total agricultural labor force. However the low economic efficiency and competitiveness of farmers in regional market, market imperfections in agriculture impedes the economic growth of this sector. This research aims to investigate gender gap in agricultural productivity among farm entrepreneurs in Kyrgyzstan. The agricultural labor productivity gap decomposed by various types of market imperfections, and empirically estimated by "Life in Kyrgyzstan" survey data for 2013 year.
\end{abstract}

\section{Introduction}

Agriculture is important livelihoods for rural population in developing countries, and understanding the dynamic processes, rapid changes in this sector gives great opportunities for economic development and poverty reduction in these countries. One fourth of all economically active women are supplying labor to agricultural market, and it is important source of employment in low income countries (Chiarini, 2017). However, there is an evidence of limited women participation in these markets, due to women discrimination to access of agricultural inputs, land, financial services, labor etc. According to World Bank (2001) addressing the gender issues and reducing gender gap in agriculture increase agricultural outputs by 10 to 20 percent. Showing that, women empowerment has positive impacts for overall household welfare, well-being and poverty reduction in low income countries (World Bank, 2009).

More than two third of total population of Kyrgyzstan are living in rural areas, and the agricultural sector of Kyrgyzstan employs nearly the half of labor force and have export oriented output production with over than 384 thousand peasant farms. The share of employed women in agriculture compromised the $44 \%$ of total agricultural labor force (NSCKR, 2016). However the low economic efficiency and competitiveness of farmers in regional market, market imperfections in agriculture impedes the economic growth of this sector, hence the share of agricultural output to GDP counts only for $16 \%$.

To address the weakness in the agriculture sector, the government of the Kyrgyzstan approved program in September 2017, where one of the prior target is to foster economic growth in agricultural sector of Kyrgyzstan. This program aims to improve economic welfare of rural households, by implementing regional rural development programs and subsidizing small farms. Taking into consider the main features of the agriculture in Kyrgyzstan, such as the dominance of small private farms, managed by self-employers, small efficiency in agricultural labor productivity and the existence of agricultural market imperfections, the aim of this paper is to unveil the main impediments of growth of agricultural labor productivity of self-employers and account for gender discrimination in Kyrgyzstan.

The estimation of agricultural productivity is based on the Palacios-López \& López (2015) method, where gender gap in agricultural productivity, decomposed among the gender discrimination in labor market, purchase of agricultural inputs and household endowments between plots managed by male-headed households and those managed by female-headed households. The data used for estimation is the "Life in Kyrgyzstan" survey data for 2013 , which is nationally representative.

This paper is structured as follows. Next section explains methodology and data. Sections 3 and 4 present estimation results and conclusion.

\section{Data and Methodology}

The estimation of labor productivity of farm entrepreneurs will be based on the "Life in Kyrgyzstan" (LIK) survey data for the 2013 year. This survey is carried out by Stockholm International Peace Research (SIPRI) with collaboration of Center for Social and Economic Research "Sotseconik" and University of Central Asia, under research project "Gender and employment in Central Asia - Evidence from Panel Data". This data is freely available for researchers from IZA's International Data Service Center (IDSC).

The LIK data consists of 3000 households, 40 communities and more than 8000 individual sample and nationally representative both at rural and urban areas of the country. This data compromises wide range of questions on economic, social and cultural topics, such as subjective well-being, education, health and personality of the individual, social life, labor market, housing, household composition and its income sources, consumption etc. 
There is special survey section for agricultural activity in the household, where the respondents were asked about cultivation of crops, lands size, production volume, sales and export values of produced products.

The empirical estimation strategy of proposed research is based on the Palacios-López \& López (2015) methodology, where the agricultural labor productivity gap among male and female headed households, is investigated based on the labor market effect, purchased inputs, household endowments and gender differences. Formally the model is given below,

$$
\begin{gathered}
Y^{F}=\beta_{0}^{F}+L^{F} \beta_{L}^{F}+\sum_{k} X_{k}^{F} \beta_{k}^{F}+\sum_{j} Z_{j}^{F} \delta_{j}^{F}+\varepsilon^{F} \\
Y^{M}=\beta_{0}^{M}+L^{M} \beta_{L}^{M}+\sum_{k} X_{k}^{M} \beta_{k}^{M}+\sum_{j} Z_{j}^{M} \delta_{j}^{M}+\varepsilon^{M}
\end{gathered}
$$

where $\mathrm{Y}$ is the land productivity, which is counted as output per hectare for male $(\mathrm{M})$ and female $(\mathrm{F})$ headed households. L is the hours spent for agricultural work, $\mathrm{X}$ is the vector of household characteristics, such as income, housing, assets, land, location and composition of the household. Here the access of women to household physical, financial and human capital shows the negotiating power between men and women within the household. And Z is the vector of agricultural good inputs, like purchase of fertilizer, pesticides, labor, etc., and this vector of variables unveils the potential gender asymmetries in the agricultural market.

The resulting coefficients from the (1) and (2) equations are used to create labor productivity variable, which is value of output per hour of managerial labor, that is the difference between land productivity (Y) and labor (L). Hence the gender gap in agricultural productivity $\left(D_{L}\right)$ given as follows:

$$
\begin{gathered}
D_{L}=\left[Y^{M}-L^{M}\right]-\left[Y^{F}-L^{F}\right] \\
D_{L}=\left[L^{M}-L^{F}\right]\left(\beta_{1}^{F}-1\right)+\sum_{k}\left[X_{k}^{M}-X_{k}^{F}\right] \beta_{k}^{F}+\sum_{j}\left[Z_{j}^{M}-Z_{j}^{F}\right] \delta_{j}^{M}+L^{M}\left[\beta_{L}^{M}-\beta_{L}^{F}\right] \\
+\sum_{K} X_{k}^{M}\left[\beta_{k}^{M}-\beta_{k}^{F}\right]+\left(\beta_{0}^{M}-\beta_{0}^{F}\right)+\sum_{J} Z_{j}^{M}\left(\delta_{j}^{M}-\delta_{j}^{F}\right)
\end{gathered}
$$

The first portion of the equation $\left[L^{M}-L^{F}\right]\left(\beta_{1}^{F}-1\right)$ gives labor market effect, in our results it is the differences in labor allocated by household head in quantities. While the second part $\sum_{k}\left[X_{k}^{M}-X_{k}^{F}\right] \beta_{k}^{F}$ gives the impact of the purchase goods, showing the gender gap in the usage of agricultural inputs. The third component $\sum_{j}\left[Z_{j}^{M}-Z_{j}^{F}\right] \delta_{j}^{M}$ shows the gender differences in the physical and human capital or household endowments, while the forth part of the equation $L^{M}\left[\beta_{L}^{M}-\beta_{L}^{F}\right]+\sum_{K} X_{k}^{M}\left[\beta_{k}^{M}-\beta_{k}^{F}\right]+\left(\beta_{0}^{M}-\beta_{0}^{F}\right)+\sum_{J} Z_{j}^{M}\left(\delta_{j}^{M}-\delta_{j}^{F}\right)$ gives gender gap explained by observed variables included in $\mathrm{L}, \mathrm{X}$ and $\mathrm{Z}$ vectors.

\section{Estimation Results}

The mean decomposition methodology has been adapted to investigate the differences in agricultural labor and land productivity for male- and female-headed households. The Table 1 reports the mean predictions by groups, in our case male and female headed households, and their differences for agricultural labor productivity. According to results there is no significant evidence of gender gap in agricultural labor productivity in both households. In our sample, the mean of agricultural labor productivity 44074 som for male headed households and 43717 som for female headed households, yielding an agricultural gap of $357 \mathrm{som}$, which is not statistically significant difference.

\begin{tabular}{l|c|c}
\hline Differential & Coef. & Std. Err. \\
\hline Female headed households & $44074.44^{* * *}$ & 8839.025 \\
\hline Male headed households & $43717.53^{* * *}$ & 3970.62 \\
\hline Difference & 356.9114 & 9689.902 \\
\hline \hline Decomposition & & \\
\hline Endowments & -4340.877 & 5236.335 \\
\hline Coefficients & $22872.21 * * *$ & 8931.998 \\
\hline Interaction & $-18174.42^{* * *}$ & 8257.246 \\
\hline Number of obs & 362 & \\
\hline$* * *$ and $*^{* *}$ show statistical significance at the 10, 5 and 1\% level, respectively.
\end{tabular}

Table 1. Blinder-Oaxaca Decomposition Estimation Results for Agricultural Labor Productivity

In the second panel of the decomposition output the agricultural productivity gap is divided into three parts. The first part reflects the mean decrease in women headed household agricultural labor productivity if their household had the same characteristics as male headed households. However in our case we couldn't find empirical evidence 
on endowments impact on agricultural productivity. While investigating the case when applying the female headed households' coefficients to the male headed household characteristics, we can see that there is statistically significant increase of labor productivity in male headed households.

The analysis was augmented by investigating whether there is statistically significant difference in agricultural land productivity of male and female headed households. For this the Blinder-Oaxaca decomposition estimation results for labor productivity has been estimated (Table 2).

\begin{tabular}{l|c|c}
\hline Differential & Coef. & Std. Err. \\
\hline Female headed households & $710.3551^{* * *}$ & 278.4263 \\
\hline Male headed households & $1456.177^{* * *}$ & 245.5198 \\
\hline Difference & $-745.8207^{* * *}$ & 371.2158 \\
\hline \hline Decomposition & & \\
\hline Endowments & -184.23 & 184.6951 \\
\hline Coefficients & -543.39 & 384.2915 \\
\hline Interaction & -18.1860 & 260.1319 \\
\hline Number of obs & 850 & \\
\hline \multirow{2}{*}{,$* *$ and $* * *$ show statistical significance at the 10,5 and 1\% level, respectively. }
\end{tabular}

Table 2. Blinder-Oaxaca Decomposition Estimation Results for Agricultural Land Productivity

According to estimation results there is statistically significant gap between male and female headed households in agricultural land productivity. The mean of agricultural land productivity 710.35 som for female headed households and 1456.17 som for male headed households, yielding significant agricultural land productivity gap of $745 \mathrm{som}$. More precisely, male headed households on average have two times more land productivity level than female headed households.

\section{Conclusions}

This study using the data from "Life in Kyrgyzstan" (LIK) survey data for the 2013 year. Taking into consider the main features of the agriculture in Kyrgyzstan, such as the dominance of small private farms, managed by selfemployers, small efficiency in agricultural labor productivity and the existence of agricultural market imperfections, the aim of this paper is to unveil the main impediments of growth of agricultural labor productivity of self-employers and account for gender discrimination in Kyrgyzstan.

The estimation of agricultural productivity is based on the Palacios-López \& López (2015) method, where gender gap in agricultural productivity, decomposed among the gender discrimination in labor market, purchase of agricultural inputs and household endowments between plots managed by male-headed households and those managed by female-headed households. The mean decomposition methodology has been adapted to investigate the differences in agricultural labor and land productivity for male- and female-headed households. In general, estimation results indicate the there is no significant evidence of gender gap in agricultural labor productivity in both households. However, there is statistically significant gap between male and female headed households in agricultural land productivity.

\section{References}

- $\quad$ Aguilar, A., Carranza, E., Goldstein, M., Kilic, T., \& Oseni, G. (2015). Decomposition of gender differentials in agricultural productivity in Ethiopia. Agricultural Economics, 46(3), 311-334.

- Ali, D., Bowen, D., Deininger, K., \& Duponchel, M. (2016). Investigating the gender gap in agricultural productivity: evidence from Uganda. World Development, 87, 152-170.

- Chiarini, A. (2017) Enhancing Opportunities for Rural Women's Employment and Poverty Reduction, "Strategies for Eradicating Poverty to Achieve Sustainable Development for All" United Nations Headquarters, New York

- Doss, C. R. (2015). Women and Agricultural Productivity: What Does the Evidence Tell Us?.

- Larson, D. F., Savastano, S., Murray, S., \& Palacios-López, A. (2015). Are women less productive farmers? How markets and risk affect fertilizer use, productivity, and measured gender effects in Uganda.

- $\quad$ Mukasa, A. N., \& Salami, A. O. (2015). Gender productivity differentials among smallholder farmers in Africa: A cross-country comparison.

- $\quad$ NSCKR (2016) Women and men in Kyrgyzstan 2011-2016. National Statistical Committee of Kyrgyz Republic, 2016

- de la O Campos, A. P., Covarrubias, K. A., \& Patron, A. P. (2016). How does the choice of the gender indicator affect the analysis of gender differences in agricultural productivity? Evidence from Uganda. World Development, 77, 17-33. 
- Palacios-López, A., \& López, R. (2015). The Gender Gap in Agricultural Productivity: The Role of Market Imperfections. The Journal of Development Studies, 51(9), 2015-08-19

- Palacios-Lopez, A., Christiaensen, L., \& Kilic, T. (2017). How much of the labor in African agriculture is provided by women?. Food Policy, 67, 52-63.

- Quisumbing, A. R., Meinzen-Dick, R., Raney, T. L., Croppenstedt, A., Behrman, J. A., \& Peterman, A. (Eds.). (2014). Gender in agriculture: closing the knowledge gap. Springer Science \& Business.

- Slavchevska, V. (2015). Gender differences in agricultural productivity: the case of Tanzania. Agricultural economics, 46(3), 335-355.

- World Bank, (2009) Gender in agriculture sourcebook / The World Bank, Food and Agriculture. Washington, DC: World Bank

- World Bank. (2001) Engendering Development—Through Gender Equality in Rights, Resources, and Voice. Washington, DC: World Bank

\section{Annex}

\begin{tabular}{c|c|c|c|c}
\hline & \multicolumn{2}{|c|}{ Male headed households } & \multicolumn{2}{c}{ Female headed households } \\
\hline & Coef. & Std. Err. & Coef. & Std. Err. \\
\hline Household size & 11946.88 & 4117.73 & 1063.888 & 2050.774 \\
\hline Adult number in HH & -10575.8 & 5915.673 & -6417.05 & 2846.069 \\
\hline Regions: & & & & \\
\hline$-\quad$ Issyk-Kul & -25014.1 & 21554.19 & -46624.7 & 18599.16 \\
\hline$-\quad$ Jalal-Abad & -23628.4 & 52130.94 & 0 & (omitted) \\
\hline$-\quad$ Naryn & 0 & (omitted) & -120.662 & 23287.85 \\
\hline$-\quad$ Batken & 35619.49 & 23938.58 & -5959 & 18681.28 \\
\hline$-\quad$ Osh & 0 & (omitted) & -18569.8 & 20011.07 \\
\hline$-\quad$ Talas & 103983.9 & 27431.4 & 14955.77 & 18632.61 \\
\hline$-\quad$ Chui & -11925.9 & 24553.05 & 29225.19 & 19676.2 \\
\hline Watering land & 1380.907 & 7235.469 & 5019.159 & 4063.999 \\
\hline Constant & 11249.24 & 27095.96 & 53323.56 & 22270.09 \\
\hline Number of obs. & 54 & & 308 & \\
\hline F stat. & 6.7 & & 6.02 & \\
\hline Prob (F stat.) & 0 & & 0.1538 & \\
\hline R-squared & 0.5436 & & 0.1282 & \\
\hline Adj R-squared & 0.4625 & & & \\
\hline \multicolumn{2}{|c|}{$* *$ and $* * *$ show statistical significance at the 10, 5 and 1\% level, respectively. }
\end{tabular}

Table 3. Estimation Results for Agricultural Labor Productivity

\begin{tabular}{|c|c|c|c|c|c|}
\hline & & \multicolumn{2}{|c|}{ Male headed households } & \multicolumn{2}{|c|}{ Female headed households } \\
\hline & & Coef. & Std. Err. & Coef. & Std. Err. \\
\hline Househ & ld size & 331.4037 & 147.3196 & -251.002 & 135.3581 \\
\hline Adult $n$ & mber in $\mathrm{HH}$ & -511.144 & 213.9135 & 535.3592 & 176.4297 \\
\hline \multicolumn{6}{|c|}{ Regions: } \\
\hline- & Issyk-Kul & -5373.23 & 1270.941 & -501.022 & 951.9077 \\
\hline- & Jalal-Abad & -6291.72 & 1389.829 & -625.529 & 939.3089 \\
\hline- & Naryn & -6142.4 & 1833.351 & 4051.275 & 1436.736 \\
\hline- & Batken & -5110.8 & 1302.523 & -958.544 & 970.8699 \\
\hline- & Osh & -5394.93 & 1216.882 & -208.693 & 869.4348 \\
\hline- & Talas & 0 & (omitted) & 0 & (omitted) \\
\hline- & Chui & -5285.89 & 1340.981 & 1594.56 & 978.452 \\
\hline Waterir & land & -393.196 & 254.5474 & -801.768 & 227.9606 \\
\hline Consta & & 6816.133 & 1467.478 & 3225.204 & 1171.252 \\
\hline Numbe & of obs. & 150 & & 700 & \\
\hline F stat. & & 3.13 & & 5.14 & \\
\hline Prob (F & stat.) & 0.0018 & & 0 & \\
\hline R-squa & & 0.1676 & & 0.0628 & \\
\hline Adj R-s & uared & 0.1141 & & 0.0506 & \\
\hline
\end{tabular}

$*, * *$ and $* * *$ show statistical significance at the 10, 5 and 1\% level, respectively.

Table 4. Estimation Results for Agricultural Land Productivity 